\title{
THE USE OF TRANSLATION IN TEACHING READING ANALYTICAL EXPOSITION TEXT
}

\author{
*Siti Kholija Sitompul \\ **Masitowarni Siregar \\ **Anni Holila Pulungan \\ Universitas Negeri Medan
}

\begin{abstract}
Kholija Siti, Sitompul. Registration Number: 2141121044. The Use of Translation in Teaching Reading Analytical Exposition Text. A Thesis. English Educational Program, State University of Medan, 2018.

This study aimed at describing the use of translation and investigating the reasons of using translation in teaching reading analytical exposition text grade eleven at MAN Peanornor. This study was qualitatively conducted that taken 3 English teachers of MAN Peanornor. The data were collected by using an interview and observing the whole process of teaching reading analytical exposition text. The findings of this study showed that there were 51 times of using translation found during three processes that they were conveying and checking meaning of words or sentences, explaining grammar and classroom management. It was also found that the use of translation was used in the scientific approach activity that experimenting and associating activity were the dominant used rather than observing, questioning and communicating activity in teaching. The reasons of using translation in teaching reading analytical exposition text were facilitating communication, teacher-student relationship and the L2 learning. The findings of this study revealed that translation contributed to the study of foreign language teaching especially teaching reading skill.
\end{abstract}

Keywords : translation, teaching and analytical exposition text.

\footnotetext{
*Graduate Status

**Lecturer Status
} 


\section{A. Introduction}

Translation, as well as receptive and productive skills plays a significant role in developing students' English mastery. Researcher Ross (2000:61) states that translation is recognized as the fifth skill and the most important social skill since it promotes communication and understanding. In this process, translation involves interaction and cooperation between people, which makes it a very useful tool in foreign language teaching. For that reason, translation is an aid to develop students' communicative skill, however the use of translation is often criticised based on two arguments. First, Shiyab (2006:115) states that translation should not be used in foreign language teaching because it causes language interference. Translation can inhibit thinking in the foreign language and can produce compound bilingualism rather than coordinate bilingualism. While, foreign language teachers have been reconsidering the use of translation for different learning purposes (Mehrabi, 2014:382). Cook (2001) states that translation activities used in the process of L2 teaching can be viewed as a rich resource which, if used judiciously, can assist second language teaching and learning.

Based on the curriculum of 2013, there are four language skills which need to be learnt by the students i.e. listening, reading, speaking, and writing. Reading is one of the receptive skills that needs to be acquired by students of senior high schools. Then, Analytical exposition text is one of the text that students of Senior High School must learn. Wayan (2014:48) states, analytical exposition text uses linguistic features consisting of relevant grammatical patterns, vocabulary usages and point of view. With regard translation, teachers have to use translation in teaching to help students in understanding the types of language in an analytical exposition text which may vary. Then, in the curriculum 2013, it uses a scientific approach as a teaching strategy using scientific steps in teaching subject matter at senior high school in Indonesia. Kemdikbud (2013) and Hosnan (2014) state that there are five steps of applying scientific approach in teaching learning process, they are observing, questioning, experimenting, associating, and communicating. In those stages, there must be a possibility of teachers teaching Indonesian students by using translation which contains detailed instructions for conducting students learning starting from observing to communicating.

From the result of observation MAN Peanornor, using translation in the classroom is helpful. The researcher believes that not all students can comprehend what teacher says in the classroom when using fully English. To make sure that they grasp the materials given, the teacher needs a medium to connect an interaction between teacher and students. That is the first language of students. Therefore, the researcher intends to know whether or not the translation in teaching reading practice is used and thus, she is interested in conducting a research which focuses on analyzing the use of translation in teaching reading Analytical exposition Text for grade eleven at MAN Peanornor.

\section{B. Theoretical Framework}

Cook (2001: 414) says some particular instances when the teacher's use of the students' L1 can be helpful for the students in the EFL-classroom. One of these is when conveying and checking meaning of words and sentences. 
Moreover, she points out that this can be useful when explaining grammar. Cook also writes that the L1 can effectively be used in classroom management including when organizing tasks and managing discipline in the classroom.

Harbord (1992) states that there are three reasons for using L1 in the classrooms. They are facilitating communication, facilitating teacher-student relationships, and facilitating the learning of L2. Cook (2001) elaborated further by stating teachers should use L1 to convey meaning and organize classrooms. Students can use L1 for scaffolding (i.e building up the basics, from which further learning can be processed) and for cooperative learning with fellow classmates. Perhaps the biggest reason for using L1 in the classroom though, is that it can save a lot of time and confusion (Harbord, 1992).

\section{Teaching Analytical Exposition Text by Using Translation}

Analytical Exposition text is a text consisting of many kinds of language features such as grammatical patterns and vocabulary usages. To achieve the competence of reading, the text is handed to the students and they are asked to underline the words that they think could be searched in dictionary or the text is translated by the teacher in to students' first language in order to understand the difficult words. Regarding with translation, Dagiliene (2012) states translation helps learners to acquire, develop and strengthen their knowledge and competence in the English language. Translation activities make students communicate both ways: into and from the foreign language. By that, teacher may use translation in teaching analytical exposition text as a learning strategy to comprehend and produce a foreign language.

\section{Research Methodology}

This study was qualitatively conducted that taken 3 English teachers of MAN Peanornor. The data were collected by using an observation of the whole process of teaching reading analytical exposition text and an interview that the teachers were given 10 questions. Observing was used to observe the teaching and learning process in order to see the teacher's used of translation in the classroom. Interviewing was used to get more data about teacher's used of translation which helped to find out the objectives the study.

\section{E. Findings and Discussion}

\section{Translation Used in Teaching Reading Analytical Exposition Text}

From the three English teachers analyzed, the totally counted that there were 51 times of using translation found during the teaching and learning itself. The following Table 4.1 will show the use of translation in teaching reading analytical exposition text.

Table 4.1 The Use of Translation

\begin{tabular}{cccc}
\hline No & Teachers & Total & Percentages (\%) \\
\hline 1. & SMA & 14 & 27 \\
\hline 2. & HS & 19 & 37 \\
\hline 3. & NG & 18 & 35 \\
\hline
\end{tabular}

From the Table 4.1, it was found that the translation were used starting from the opening till the closing of teaching reading analytical exposition text in 90 
minutes. It was also found that teacher 1 only used translation (EnglishIndonesian or Indonesian-English) for 14 times. When the material should be clearly delivered, teacher 1 decided to use fully Indonesian to the students. While teacher 2 decided to use English then translated the material in to Indonesian for 18 times. Then, teacher 3 used English and translated the material in to Indonesian to make it clear for 19 times. For more, the use of translation from each process is described below:

\section{a. Conveying and Checking Meaning of Words and Sentences Process \\ 1. Data 1 of Teacher 1 (SMA)}

a) Opening Activity

1. Who doesn't come today? Siapa yang gak hadir hari ini?

2. Today, we want to discuss a material namely analytical exposition text. Have you ever learned this analytical exposition text? Sudah pernah belajar teks ini?

3. Yakin? Are you Sure?

b) Core Activity

1. Nah, Analytical Exposition Text ini adalah teks yang menjelaskan tentang pengetahuan di dalam kehidupan sehari-hari. So, it is a text that elaborates a phenomenon surroundings by a writer.

2. Contohnya tentang merokok "smoking", contoh yang lain "bahaya dari mobil - The danger of car". Narkoba "drugs". Any else? Ada lagi? Bencana alam "natural disaster".

3. Nah, di dalam teks ini (In this text), ada 3 unsur teks analytical exposition ini. There are 3 elements of analytical exposition text.

4. The first is thesis. Thesis ini adalah sebagai pembuka suatu paragraph (This thesis is an opning of a paragraph). Dan thesis ini adalah pandangan, main idea of the writer about the text. Pandangan awal oleh penulis tentang teks (The first view of a writer about the text).

5. Pendapat yang dapat menunjang thesis atau pandangan awal tadi. Argument is to strengthen the thesis. Kemudian yang terakhir, kesimpulan atau the last disebut dengan reiteration (The last is reiteration).

6. Ok, Martua. Can you find the thesis? Bisakah kamu temukan yang mana thesisnya?

7. Ingat aja tandanya, kalau argumennya lebih dari satu, biasanya ada penandanya (Remember the clue, if the arguments are more than one). There is a clue.

\section{c) Closing Activity}

There is no data related to the process in the closing activity. The teacher just used English to close the material and it was understandable by the students.

\section{Data 2 of Teacher 2 (HS)}

a) Opening Activity

1. Who doesn't come, today? Ada yang tidak datang hari ini?

b) Core Activity

1. Misalnya, bahwasanya merokok itu lebih banyak bahayanya terhadap kesehatan atau tubuh manusia (For example, smoking is dangerous or health or people's body). Smoking is very bad for health. 
2. Kalo thesisnya boleh diawali dengan (The thesis can be started with) smoking is bad for health "bahwa merokok tidak baik untuk kesehatan".

3. If you are fat, jika kamu gemuk, jantungmu lebih rentan cepat bekerja (your heart has to work harder).

4. Anyone can tell me the other arguments? Ada yang tau mana lagi argumennya?

5. In addition artinya selain itu (The meaning of in addition is selain itu). Amount of your blood itu kadar gula. Furthermore adalah selanjutnya.

6. As far as I explained, sejauh yang Ibu jelaskan tadi, semua sudah paham kah? Mangarti do kan?(Do you see what I have explained?)

7. Jadi, analytical exposition text is a text that explains an event or fact surroundings atau teks yang memaparkan kejadian atau peristiwa di sekitar.

8. For example, the danger of drug or the danger of smoking "bahaya merokok" atau teks yang kita analisis tadi (or the text that we analyzed) "being fat is a serious problem".

9. Gak usah (No), itu PR saja di rumah ya. It is your homework.

c) Closing Activity

There is no data related to the process in the closing activity. The teacher just used English to close the material and it was understandable by the students.

3. Data 3 of Teacher 3 (NG)

a) Opening Activity

There is no data related to the process in the opening activity. The teacher had opened the class and checked the attendance list in the Math Class. In other words, this English teacher is a Math teacher also.

b) Core Activity

1. Miss mau nanya, pernah gak kalian berargumen atau berpendapat? (I am going to ask you, have you ever given an argument or opinion?) Give an argument?

2. Ever or never? Pernah atau tidak?

3. Nah, when you see, atau ketika kamu melihat sebuah masalah, pasti kamu berargumen kan?(You will give an argument, right?)

4. Iya, It should be decorated and cleaned more so that looks beautiful. Kelas ini harusnya dihiasi lagi kan?

5. Banjir itu flood ya nak.

6. Iya, lebih spesifik kalo air pollution (Yes, air pollution is the specific problem). Polusi udara.

7. Iya. The rise of fuels cause unprosperity to the society of Indonesia. Kenaikan BBM mempengaruhi kesejahteraan masyarakat Indonesia.

8. Okay, berarti ongkos transport ya. The cost of driving a public transportation.

9. Anything else? Selain itu apalagi?

10. Am I clear? Jelas? Jelas do kan? Na pudi? (The students who sit in the backward?) 
11. Ingat ya, kalo thesis itu selalu diletak di awal paragraph (Just remember, that thesis will always be in the first paragraph). It is in the first paragraph.

12. Jadi, analytical exposition text is a text that explains a fact that happens in our environment. Teks ini berbicara tentang kejadian di lingkungan sekitar kita. For example: PT SOL, pollution, the use of car "Penggunaan mobil".

c) Closing Activity

1. Close your book please. Tutuplah bukunya.

b. Explaining Grammar Process

1. Data 1 of Teacher 1 (SMA)

From the teacher 1, there is no data related to this process starting from the opening till the closing activity because the teacher just focused on teaching the material.

2. Data 2 of Teacher 2 (HS)

a) Opening Activity

There is no data related to the process in the opening activity because it just prayed and checked the attendance of students.

b) Core Activity

1. Di analytical exposition ini kita make tenses apa? What tenses we use here?

2. Simple Present Tense tells the habitual activity and facts. Simple Present Tense ini tentang kegiatan sehari-hari dan juga fakta.

3. For example, have dan has. Taunya kan arti have dan has? "Ya, Mempunyai" (Do you know have and has?). Masih ingat kan siapa yang make have dan has? Remember?

4. Have itu dipakai oleh I, you, we dan they (Have is used by I, you, we and they). But, has is used for he, she dan it.

5. Yes, in the first paragraph, ada "know, is, have dan cause" (There is the verb know, is and have). All the verbs are simple present tense. Semuanya contoh kata kerja Simple Present.

c) Closing Activity

There is no data related to the process in the closing activity because it just assigned the students to do homework.

3. Data 3 of Teacher 3 (NG)

a) Opening Activity

There is no data related to the process in the opening activity. The teacher just began the material.

b) Core Activity

1. It should be decorated. Harusnya kelas ini didekorasi. Kan ini kalimat pasif (That' a passive voice).

2. Karena lebih dari satu, so there are three elements of the generic structure of analytical exposition. Bukan there is.

c) Closing activity

There is no data related to the process in the closing activity. The teacher just asked the students to close book and say hamdalah.

c. Classroom Management Process

1. Data 1 of Teacher 1 (SMA) 


\section{a) Opening Activity}

There is no data related to the process in the opening activity.

b) Core Activity

1. Ok, now. Please make a group. A group consists of 4 students. Tolong bentuk dulu grupnya. Setiap grup terdiri dari 4 orang.

2. Di selembar kertas. In a piece of paper ya nak.

3. Please look at the paper I give you. Coba perhatikan teks yang di kertas yang Ibu bagi.

4. Ok. Read please. Bacalah nak.

c) Closing activity

There is no data related to the process in the closing activity.

2. Data 2 of Teacher 2 (HS)

\section{a) Opening Activity}

There is no data related to the process in the opening activity.

b) Core Activity

1. Nah, I want to divide you in several groups. Saya akan membagikan kalian ke dalam beberapa grup.

2. 4 orang ya, nak. 4 students ya.

3. Now look at the examples, perhatikan contoh yang Ibu bagikan.

4. Iya, jadi kalau sudah paham, look at text 2. Di lembar yang ibu bagi ke kalian ada teks tentang "car". I want you read this text and answer the five questions. Kalian baca dulu teksnya dan jawab ya. And analyze the text by showing the generic structure of the text.

c) Closing Activity

There is no data related to the process in the closing activity.

3. Data 3 of Teacher 3 (NG)

a) Opening Activity

There is no data related to the process in the opening activity.

b) Core Activity

1. I want all of you read the text in the book on page 33. Miss mau kalian baca dan coba garis bawahi generic structure dari teks analytical exposition ini.

2. Do it with your bench mate. Kerjakan dengan teman sebangku kamu.

3. Now, there is a text in your book about analytical exposition paragraph. Answer the questions. Jawab pertanyaanya, cuma 5 soal. Then, tambahannya find the generic structure ya. Which one is thesis, argument and conclusionnya.

c) Closing Activity

There is no data related to the process in the closing activity.

From the data obtained, the use of translation in teaching reading analytical exposition text was found in the scientific approach activity that was the core activity of teaching. It can be seen in the following below:

\section{a. Observing}

\section{Teacher 1 (SMA)}

Based on the data obtained, there is one data related to the observing activity "bahaya dari narkoba or the danger of drugs, ada gak di lingkunganmu? (Is it in your environment, right?)".

\section{Teacher 2 (HS)}


Based on the data obtained, there is no data related to this activity.

\section{Teacher 3 (NG)}

Based on the data obtained, there is one data related to the observing activity "Nah, when you see the problem, atau ketika kamu melihat sebuah masalah, pasti kamu berargumen kan?".

b. Questioning

1. Teacher 1 (SMA)

Based on the data obtained, there is one data related to the questioning activity, "Today, we want to discuss a material namely analytical exposition text. Have you ever learned this analytical exposition text? Sudah pernah belajar teks ini?

\section{Teacher 2 (HS)} activity.

Based on the data obtained, there is no data related to the questioning

\section{Teacher 3 (NG)}

Based on the data obtained, there is one data related to the questioning activity namely "Miss mau nanya, pernah gak kalian berargumen atau berpendapat? (I'm going to ask you, have you ever given an argument or opinion?). Give an argument? ".

\section{c. Experimenting}

\section{Teacher 1 (SMA)}

a. Ok, now. Please make a group. A group consists of 4 students. Tolong bentuk dulu grupnya. Setiap grup terdiri dari 4 orang.

b. Nah, di dalam teks ini, ada 3 unsur teks analytical exposition ini. There are 3 elements of analytical exposition text.

c. The first is thesis. Thesis ini adalah sebagai pembuka suatu paragraf. Dan thesis ini adalah pandangan, main idea of the writer about the text. Pandangan awal oleh penulis tentang teks.

d. Pendapat yang dapat menunjang thesis atau pandangan awal tadi. Argument is to strengthen the thesis. Kemudian yang terakhir, kesimpulan atau the last disebut dengan reiteration.

\section{Teacher 2 (HS)}

a. Misalnya, bahwasanya merokok itu lebih banyak bahayanya terhadap kesehatan atau tubuh manusia. Smoking is very bad for health.

b. Kalo thesisnya boleh diawali dengan smoking is bad for health "bahwa merokok tidak baik untuk kesehatan". (the thesis can be started with smoking is bad for health).

\section{Teacher 3 (NG)}

a. Iya, It should be decorated and cleaned more so that looks beautiful. Kelas ini harusnya dihiasi lagi kan?

b. Banjir itu flood ya nak.

c. Iya, lebih spesifik kalo air pollution. Polusi udara.

d. Iya. The rise of fuels cause unprosperity to the society of Indonesia. Kenaikan BBM mempengaruhi kesejahteraan masyarakat Indonesia.

e. Okay, berarti ongkos transport ya. The cost of driving a public transportation.

f. Ingat ya, kalo thesis itu selalu diletak di awal paragraf. It is in the first paragraph. 
g. Jadi, analytical exposition text is a text that explains a fact that happens in our environment. Teks ini berbicara tentang kejadian di lingkungan sekitar kita. For example: PT SOL, pollution, the use of car "Penggunaan mobil".

d. Associating

1. Teacher 1 (SMA)

a. Ok, Martua. Can you find the Thesis? Bisakah kamu temukan yang mana thesisnya?

b. Ingat aja tandanya, kalau argumennya lebih dari satu (Just remember, if the arguments are more than one), biasanya ada penandanya. There is a clue.

2. Teacher 2 (HS)

a. If you are fat, jika kamu gemuk, jantungmu lebih rentan cepat bekerja (your heart has to work harder).

b. Anyone can tell me the other arguments? Ada yang tau mana lagi argumennya?

c. In addition artinya selain itu. Amount of your blood itu kadar gula. Furthermore adalah selanjutnya.

d. As far as I explained, sejauh yang Ibu jelaskan tadi, semua sudah paham kah? Mangarti do kan?(Understand?)

3. Teacher 3 (NG)

"Ingat ya, kalo thesis itu selalu diletak di awal paragraf. It is in the first paragraph".

e. Communicating

1. Teacher 1 (SMA)

Based on the data obtained, there is no data related to this activity.

2. Teacher 2 (HS)

a. Jadi, analytical exposition text is a text that explains an event or fact surroundings atau teks yang memaparkan kejadian atau peristiwa di sekitar.

b. For example, the danger of drug or the danger of smoking "bahaya merokok" atau teks yang kita analisis tadi "being fat is a serious problem".

c. Gak usah, itu PR saja di rumah ya. It is your homework.

3. Teacher 3 (NG)

Based on the data obtained, the use of translation in this activity was only "Jadi, analytical exposition text is a text that explains a fact that happens in our environment. For example: PT SOL, pollution, the use of car 'Penggunaan mobil".

2. The Reasons of Using Translation Reading Analytical Exposition Text

a. Facilitating communication

1. Teacher 1 : SMA

a. Who doesn't come today? Siapa yang gak hadir hari ini?

b. Today, we want to discuss a material namely analytical exposition text. Have you ever learned this analytical exposition text? Sudah pernah belajar teks ini?

c. Yakin? Are you Sure?

d. Ok, now. Please make a group. A group consists of 4 students. Tolong bentuk dulu grupnya. Setiap grup terdiri dari 4 orang.

2. Teacher 2 : HS 
a. Nah, I want to divide you in several groups. Saya akan membagikan kalian ke dalam beberapa grup.

a. Di analytical exposition ini kita make tenses apa? What tenses we use here?

b. Simple Present Tense tells the habitual activity and facts. Simple Present Tense ini tentang kegiatan sehari-hari dan juga fakta.

c. For example, have dan has. Taunya kan arti have dan has? "Ya, Mempunyai" (Do you know have and has?). Masih ingat kan siapa yang make have dan has? Remember?

d. Have itu dipakai oleh I, you, we dan they (Have is used by I, you, we and they). But, has is used for he, she dan it.

e. Yes, in the first paragraph, ada "know, is, have dan cause" (There is the verb know, is and have). All the verbs are simple present tense. Semuanya contoh kata kerja Simple Present.

\section{Teacher 3 : NG}

a. I want all of you read the text in the book on page 33. Miss mau kalian baca dan coba garis bawahi generic structure dari teks analytical exposition ini (and try to underline the generic structure of the analytical exposition text).

b. Do it with your bench mate. Kerjakan dengan teman sebangku kamu.

c. Now, there is a text in your book about analytical exposition paragraph. Answer the questions. Jawab pertanyaanya, cuma 5 soal. Then, tambahannya find the generic structure ya. Which one is thesis, argument and conclusionnya.

b. Facilitating teacher-student relationships

1. Teacher 1 : SMA

a. Di selembar kertas. In a piece of paper ya nak.

b. Please look at the paper I give you. Coba perhatikan teks yang di kertas yang Ibu bagi.

c. Ok. Read please. Bacalah nak.

d. Ok, Martua. Can you find the thesis? Bisakah kamu temukan yang mana thesisnya?

2. Teacher 2 : HS

a. 4 orang ya, nak. 4 students ya.

b. Now look at the examples, perhatikan contoh yang Ibu bagikan.

c. Iya, jadi kalau sudah paham, look at text 2. Di lembar yang ibu bagi ke kalian ada teks tentang "car". I want you read this text and answer the five questions. Kalian baca dulu teksnya dan jawab ya. And analyze the text by showing the generic structure of the text.

d. Anyone can tell me the other arguments? Ada yang tau mana lagi argumennya?

e. In addition artinya selain itu (The meaning of in addition is selain itu). Amount of your blood itu kadar gula. Furthermore adalah selanjutnya.

f. As far as I explained, sejauh yang Ibu jelaskan tadi, semua sudah paham kah? Mangarti do kan?(Do you see what I have explained?)

g. Gak usah (No), itu PR saja di rumah ya. It is your homework.

\section{Teacher 3 : NG}

a. Miss mau nanya, pernah gak kalian berargumen atau berpendapat? (I'm going to ask you, have you ever given ar argument or opinion?) Give an argument? 
b. Ever or never? Pernah atau tidak?

c. Nah, when you see, atau ketika kamu melihat sebuah masalah, pasti kamu berargumen kan?

\section{c. Facilitating the learning of $\mathrm{L} 2$}

\section{Teacher 1 : SMA}

a. Nah, Analytical Exposition Text ini adalah teks yang menjelaskan tentang pengetahuan di dalam kehidupan sehari-hari. So, it is a text that elaborates a phenomenon surroundings by a writer.

b. Contohnya tentang merokok "smoking", contoh yang lain "bahaya dari mobil - The danger of car". Narkoba "drugs". Any else? Ada lagi? Bencana alam "natural disaster".

c. Nah, di dalam teks ini (In this text), ada 3 unsur teks analytical exposition ini. There are 3 elements of analytical exposition text.

d. The first is thesis. Thesis ini adalah sebagai pembuka suatu paragraph (This thesis is an opning of a paragraph). Dan thesis ini adalah pandangan, main idea of the writer about the text. Pandangan awal oleh penulis tentang teks (The first view of a writer about the text).

e. Pendapat yang dapat menunjang thesis atau pandangan awal tadi. Argument is to strengthen the thesis. Kemudian yang terakhir, kesimpulan atau the last disebut dengan reiteration (The last is reiteration).

\section{Teacher 2 : HS}

a. Misalnya, bahwasanya merokok itu lebih banyak bahayanya terhadap kesehatan atau tubuh manusia (For example, smoking is dangerous or health or people's body). Smoking is very bad for health.

b. Kalo thesisnya boleh diawali dengan (The thesis can be started with) smoking is bad for health "bahwa merokok tidak baik untuk kesehatan".

c. If you are fat, jika kamu gemuk, jantungmu lebih rentan cepat bekerja (your heart has to work harder).

d. Jadi, analytical exposition text is a text that explains an event or fact surroundings atau teks yang memaparkan kejadian atau peristiwa di sekitar.

e. For example, the danger of drug or the danger of smoking "bahaya merokok" atau teks yang kita analisis tadi (or the text that we analyzed) "being fat is a serious problem".

\section{Teacher 3 : NG}

a. Iya. The rise of fuels cause unprosperity to the society of Indonesia. Kenaikan BBM mempengaruhi kesejahteraan masyarakat Indonesia.

b. Okay, berarti ongkos transport ya. The cost of driving a public transportation.

c. Ingat ya, kalo thesis itu selalu diletak di awal paragraf. It is in the first paragraph.

d. Jadi, analytical exposition text is a text that explains a fact that happens in our environment. Teks ini berbicara tentang kejadian di lingkungan sekitar kita. For example: PT SOL, pollution, the use of car "Penggunaan mobil".

To reveal the teachers' view in using translation as L2 learning practice, the teachers were given some questions, identifying their views to which they agreed or disagreed with translation. The respondents can be seen in the following:

\section{Teacher 1 SMA}


Teacher 2 claimed that she used translation due to the students' ability in English are very low. The decision to use translation in English class when there are many students do not really understand to the materials given..

\section{Teacher 2 HS}

Teacher 2 claimed that she used translation in teaching in order to make the students quickly understand. Teaching English without using translation will makes the students do not know what to do.

\section{Teacher 3 NG}

Teacher 3 claimed that many students could not catch the point of the material when it was delivered in English. The decision to use translation or the first language of students based on the situation.

\section{F. DISCUSSION}

In English teaching, translation has been widely used as a pedagogical tool. Translation is considered the most important skill by the teachers because it promotes understanding and communication between teacher and students. This study highlighted that translation is really helpful in teaching and learning practice in order to make sure whether the students understand or not. The teacher frequently used the translation itself.

The obtained data was supported by a video-recording during the teaching and learning process. It can be seen from the result of this study that there were 51 times of using translation in the classroom by three English teachers. Translation was used in conveying and checking meaning of words or sentences process, explaining grammar process and classroom management process. The use of translation was also found in the scientific approach activity. It was often used in experimenting and associating activity rather than observing, questioning and communicating activity. The reasons of using translation were facilitating communication, facilitating the relationship between teacher and students and facilitating the L2 learning. The findings above give contributions on the study of English as a foreign language. It can be proved that translation is helpful in teaching and learning practice. Thus, it can be said as a pedagogical tool in teaching that may build the communication and relationship between teacher and students in classroom.

\section{G. Conclusion}

The findings of the study confirm that:

1. Translation was used by the three English teachers in teaching reading analytical exposition text in the process of conveying and checking meaning of words or setnences, explaining grammar and classroom management. It was also used in the scientific approach that experimenting and asscoiating activity were the dominant used of using translation.

2. The reasons of using translation were facilitating communication, teacherstudent relationship and the L2 learning. When the teachers used translation in teaching reading analytical exposition text, it might facilitate the communication and achieve the target of L2 learning. Then, it also built the relationship between the teachers and students that the students may ask everything when they encounter. 


\section{References}

Cook, G. (2010). Translation In Language Teaching: an argument for Reassessment. London: Oxford University Press.

Cook, V. J. (2001). Using the first language in the classroom. Canadian Modern Language Review, 57(3), 184-206.

Kherad Ranjbar, M. (2015). The Comparative Impact of Reading Comprehension and Translation Practices on EFL Learners' Grammar Achievement. In : Journal of Studies in Education. 5(4), 51-73.

Kim Pham, C. T. (2017.) Reading Comprehension and Translation Performance of English Linguistics Students of Hung Vuong University: A Correlational Study. International Journal of English Language \& Translation Studies, 5(3), 79-85.

M. Zaim. (2017). Implementing Scientific Approach to Teach English at Senior High School in Indonesia. Canadian Center of Science and Education, 13(2), 33-40.

Mehrabi, B. A. (2014). Pedagogical Utility of Translation in Teaching Reading Comprehension To Iranian EFL Learners. International Journal of Language Learning and Applied Linguistics World, 5(2), 381-395.

Ross, N. J., (2000). Interference and Intervention: Using Translation in the EFL Classroom. Modern English Teacher, 9(3), 61-66.

Shiyab, S. (2006). A Textbook of Translation: Theoretical and practical implications. Antwerp: Garant. 